\title{
Birth and Rebirth: the Past, Present and Future of Albanian Transition
}

by

\author{
by Emily Pearce
}

"I listened curiously, racking my brain trying to understand exactly what was this Albania they were so worried about. Was it everything I saw around me: courtyards, streets, clouds, words, Xhexho's voice, people's eyes, boredom or only a part of all of that?"

- Ismail Kadare, Chronicle in Stone

Not much is known about Albania outside Albania. Indeed few people outside Europe can locate it on a map, and even fewer could tell you anything significant about its history or political situation. Despite its relative obscurity the fate of this small south eastern Mediterranean country is relevant to the objectives of the European and international communities while simultaneously being influenced by them. Emerging from nearly 50 years of total isolation, Albania's transition from communism to liberal democracy has been a long and arduous one marked by political and economic crises bringing the country to the brink of civil war.

The current situation in Albania is stable, but this stability is tenuous and is held in place only by a social and political order which has resigned itself to corruption and shadowy dealings. In this climate Albania has become a society of open secrets, a dichotomous nation operating on disparate levels--a paradoxical order which the Albanians are currently trying to reconcile in hopes of joining Europe. It would be unfortunate were the international community to overlook the ongoing struggle of this country. An understanding of its history, its current political climate and the challenges it faces could help the international community make Albania a success story in the struggle for democracy and stability.

This paper will explore the history of Albanian transition, the current state of affairs, and finally the role the international community can play in consolidating a stable and democratic future for Albania.

\section{Albania during Transition: From Communism to Crisis}

When dictator Enver Hoxha died in 1985, ending his 40 year reign, he likely did not know that his monolithic Stalinist regime's days were numbered. All across the Soviet space the winds of change were blowing, but not in Albania. In fact "there was little dissent within the country and no inclination on the part of communist rulers to follow Gorbachev's reforms in the Soviet Union." (Elbasani 2004; 33) The country, which had been totally isolated from the rest of the world since it broke with the Soviet Union during Khrushchev's 1950's de-Stalinization period, was still ruled by a 
one-party communist state. It was not until the revolution in Romania that Hoxha's successor Ramiz Alia began to initiate some market reforms in February 1990 in an attempt to avert dissension. By 1991 however Alia's refusal to extend these reforms to political liberalization had led to widespread protests and the beginnings of a massive emigration to Italy and Greece. Bowing to pressure in March 1991 the first multiparty election was organized with the newly created Democratic Party winning a respectable $38 \%$ of votes, but not enough to oust the Communist Party which won a ruling majority. Protests and strikes raged amid reports of restrictions on civil society, unequal access to the media and intimidation of opposition published by international observers. (NDI 1991, Human Rights Watch 1991) Bowing to pressure a second election was held giving the Democratic Party led by Sali Berisha an overwhelming majority.

The legacy left to Berisha from the communist caretakers was a difficult one, "Albania remained the least economically developed country in Europe. The low GDP per capita put it firmly in the African category of low-income countries" (Elbasani 2004; 33). None the less Albania's economy under the first years of the Berisha government rallied considerably. Between 1993 and 1995 GDP growth averaged around 10\% and inflation decreased dramatically, into the single digits. (Jarvis 2000) However, the excitement surrounding the first years of popular democracy and the steadily increasing GDP bellied an undercurrent of institutional weakness; weakness that would eventually lead to the collapse of the entire Albanian political and economic system. Structural reform in the banking sector was developed slowly. The three state banks were seen as unreliable and private sector banks were slow to emerge due to the lack of formal financial sector framework. A large majority of Albanians retained their savings in cash and were reluctant to deposit in banks. The insufficient regulation of banks resulted in the granting of too many loans in the frenzy over the new market economy. By 1995 outstanding or un-performing loans were such a problem that the government instituted a cap on the amount of money banks could distribute. This led Albanians to seek other sources of investment or credit. In the presence of this informal financial system pyramid schemes began to crop up. By promising, and initially providing, high returns on investment these companies began to recruit a significant number of small investors. A good percentage of the money was likely funneled into illegal activities surrounding drug and human trafficking. (Jarvis 2000)

Between November 1996 and January 1997 the predicted consequences of the unregulated illegal economic system came to fruition, as three of the largest pyramid scheme companies collapsed. What was not predicted was the chaos that ensued. By February the army and police had mostly deserted. By mid-March armories were being looted and evacuation of foreign nationals and mass emigration of Albanians to Italy began. On April $15^{\text {th }}$ 2007, just over six years since the first democratic elections, the UN sent in a multinational force of 7,00o led by Italy to restore order in the wake of the institutional collapse. The election held in June, won by the Socialist Party, signaled the restoration of civil order. 
While obviously linked to regulatory problems the economic collapse also illustrated a fundamental problem of governance. Lack of transparency and accountability meant "that members of the government themselves benefited from and supported the [pyramid scheme] companies." (Jarvis 2000; 8) Even to the extent that during the 1996 elections a number of the major companies made contributions to the ruling Democratic Party campaign and paid for advertisements on the election posters of candidates. "This tolerance was reflected in the benign neglect of both the Ministry of Justice and the Ministry of Finance and in open support of the major companies by the President." (Ibid) This type of corruption and misuse of power was able to flourish in "the literal vacuum of the economy, social services, law and order that had all broken down," a situation that, as we will see, has continued to resist reform to this day. (Elbasani 2004; 34)

\section{Starting Over: Recent Achievements and Challenges}

The period starting from the institution of the new government in June 1997 to present day has been a period of starting over for Albania. Since the 1997 crisis Albania has slowly began to rebuild a second time. In these 10 years steady increases in economic growth and political reform have given Albania a new lease on democratic transition. Electoral reforms taking place between 1997 and 2002 strengthened the democratic structures including a new constitution which was ratified in 1998 by popular referendum. Since 1998 the GDP has steadily increased, reaching a growth rate of over 5\% in 2006 and unemployment has been steadily declining. (US Dept of State 2008)

But both Albanians and the international community should take these indications of progress with a grain of salt. An examination of the current situation in Albania could arguably demonstrate that all the wrong lessons were learned from the crisis, if any at all. On the political side corruption permeates every level of the Albanian government. The current political structure has allowed for the concentration of prime ministerial power. A high degree of civil servant replacement upon change of government is contributing to the stagnation of reforms. Short mandates for civil servants means a lack of the continuity needed to fulfill long-term plans and also means resources and time are wasted on vying for favour from those in power. Additionally, the judiciary is not sufficiently independent, stemming from parliamentary influence in the assignment of cases. As well there is an insufficient level of constitutional protection and accountability for judges. (Europa 2007) There are, none the less, a number of reform projects underway. Unfortunately many are inhibited by the barriers existing within the system which make substantial change near impossible.

Examples of the highly unaccountable nature of government structures abound. As of 2006 a government proposal to lift the immunity of members of parliament against prosecution for corruption was held up as it needed a 3/5 parliamentary majority to pass. The absurd irony of such a situation seems indicative of an Albania whose current Prime Minister is the same Sali Berisha who led them into an economic 
collapse resulting in a violent crisis less than 10 years ago. This is buttressed by the fact that voting procedures within the parliament still lack transparency. The economic situation is not substantially better. After the crisis a number of reforms and regulations were put into place to try to avoid a repeat situation. But this is of little help when an estimated 50\% of the Albanian economy is derived from the informal sector. (Albania 2008) This ranges from illegal human and drug trafficking to Small and Medium Enterprises (SMEs) with inadequate financial reporting. Combined with the over the $15 \%$ or 600 million dollars that come from migrant remittances, a significant percentage of the Albanian economy does not interact at all with the Albanian financial structure. The reasons for this are several fold. Aside from the obvious illegality of some of these transactions, confidence in banking continues to be weak. Further, services offered by the State ranging from roads to electricity to health services are inadequate at best. Dealing in cash allows families to access to income they need to supplement services and circumvent paying taxes to a government perceived as corrupt and inefficient.

What is most interesting for a visitor to Albania is how this system marked by bribery, inefficiency, outflows of migration and corruption can possibly function. In many ways Albania exists on two plains; the legitimate and the informal. Albanians have come to live a double life, constantly shifting between the two faces of their country. If you ask the average Albanian how they feel about the hours of power outages or having to bribe doctors for sufficient care, resignation seems almost totally pervasive. And yet their participation in the system is part of the problem. Illegal power lines and non-payment of energy bills is a great contributor to the energy crisis, meanwhile this situation persists because the government and the power companies do not have sufficient means of penalty and collection. Albanians feel that as long as the roads are not paved, electoral practices are questionable, and greased palms are the only way to get things done, they might as well use the loopholes in the system to at least achieve some reasonable standard of living. It will be Albania's greatest challenge to create an environment of trust and accountability that will legitimize the formal system.

Let us none the less give credit where credit is due. On some levels the change is staggering. In less than two decades the country has opened up to opportunities inconceivable during the communist period. The business climate has greatly improved, with a huge increase in Foreign Direct Investment and greater access to licenses for private businesses. Opportunities for young people to study abroad as well as high levels of migration have meant a high influx of human, social and intellectual capital are creating a greater pool of skills and expertise. Unfortunately the benefits of any such capital, including economic, are located almost entirely in the urban areas. The population of the capital, Tirana, has exploded since a period of massive internal migration led huge numbers to leave impoverished, subsistencebased rural areas in search of employment. Both rights and interest in public engagement have also improved. There are several NGOs and think-tanks that work with international organizations to take on the issues that Albania continues to face. Perhaps the most notable is MJAFT, an independently funded youth organization 
which raises public awareness and organizes parliamentary monitoring.

\section{$\underline{\text { A Return to Europe: Albania Under International Influence }}$}

This leads us to the future of Albania and its place in the international order. One of the great promises of the newly emerging opposition parties in the early 1990's was a 'return to Europe'. At that time this meant the adoption of a western European freemarket and liberal democratic system. Today a 'return to Europe' means something more specific. Albania harbors ambitions of eventual European Union membership. Euro-Atlantic Cooperation has become a defining factor in Albania foreign policy. Because of the strong demands for accountability, transparency, economic stability and security that accompany cooperation, reforms have become necessary in all policy realms. The necessity of reform has driven much of the progress made in Albania in recent years and has determined the agenda of future reforms. There are hopes that the first steps towards international cooperation have been made and that Albania will be asked to join NATO at their annual summit in Bucharest in April 2008.

In 2006 the EU signed a Stability and Association Agreement (SAA) with the Albanian government. As a result of the substantial requirements associated with EU cooperation many changes have been made. For example, fighting between parties has been a hindrance to carrying out reforms but in January 2008 a parliamentary resolution for unconditional cooperation between the parties regarding judiciary and electoral reform was passed. The implementation of such measures is demanded by NATO and the EU of countries being considered for membership and will greatly contribute to the progress of reforms. Organized crime, which has long been a problem in Albania, is high on the EU agenda and thanks to EU pressure a great deal of progress has been made on this front, including mass arrests and extraditions. (Hala 2008) Recommendations that Albania continue to enhance structural reforms to be able to solidify progress thus far made by stabilization programs have led the Albania government to set aside an ambitious $822 \mathrm{~m}$ Euros (or 20\%) of the budget for infrastructure (Neza 2008). But these are just a few first steps towards EU membership which requires the adoption of a staggering 90,000 pages of regulations set out in the acquis communautaire. 1 Meaning that Albania still has a long way to go before attaining

But even if Albania is unlikely to accede to the EU any time soon--earliest predictions are for 2020--Albania's development should not be overlooked by the EU or the international community. Albania is on the cusp of successful transition and the will is there: popular support for EU and NATO membership is upwards of 90\% (Dujisin). The seeds of economic and institutional reform have been planted. The EU, even limiting itself to cooperation, and NATO with membership either this year or in the future, as well as national foreign policies have the capacity to give Albania the push it needs. The controversy currently surrounding the newly declared independence of Kosovo means that the North Atlantic community could use a stable ally in the region. Bodies like the European Union and NATO could have a tremendous impact 
on Albanian transition through monitoring as well as economic and technical cooperation. They can further exert influence by assuring both the Albanian people and the government that compliance and cooperation will garner rewards and regression incur penalties. While there has recently been criticism surrounding both the effectiveness and the imperialist nature of the west's "carrot" and "stick" approach to triggering reform Albania has already shown a great willingness to join the 'club of Europe'. This willingness and the pressure exerted by the EU have so far facilitated some progress in economic and political reform. The consensus in Albania around the adoption of western style reforms could give the international community the opportunity to unify the divided and skeptical country while simultaneously giving an air of legitimacy to western strategies for promoting democracy and stability.

$\underline{1}$ The body of Community legislation by which all EU Member States are bound. Countries joining the EU must have implemented the existing acquis communautaire by the time of accession

\section{$\underline{\text { References }}$}

U.S Department of State.(2008). “Albania: Background Note.” Bureau of European and Eurasian Affairs.

http://www.state.gov/r/pa/ei/bgn/3235.htm\#geo

NDI (1991) “Albania: 1991 Elections to the People's Assembly: A Post-Election

Report, April 30, 1991.” National Democratic Institute. April 30, 1991

Europa.(2007). “Albania 2007: Progress Report.” COM 2007 (Final)Brussels, 6.11.2007 1429. Commission Staff Working Document.

Dujisin, Zoltan.(2008) "ALBANIA: Heading for NATO, as a Gateway to the EU." Italy: Inter Press Service. Feb. 21, 2008.

http://www.ipsnews.net/news.asp?idnews=41294

Elbansani, Arolda (2004). "Albania in Transition: Manipulation or Appropriation of international norms.” Southeast European Politics. Vol. V, No. 1. p 24-44.

Hala, Manola.(2008) “Albania boots efforts for NATO membership.” Tirana:

Southeast European Times. Feb.4, 2008.

http://www.setimes.com/cocoon/setimes/xhtml/en GB/

features/setimes/features/2008/02/04/feature-02

Human Rights Watch. (1991) "Albania: Human Rights Development”. As reported in the State Department's Dispatch, March 25, 1991. http://www.hrw.org/

reports/1992/WR92/ HSW-01.htm

Illirjani, Altin.(2004) “Albania and the European Union”. Mediterranean Politics. 
Summer2004, Vol. 9 Issue 2, p258-264,

Jarvis, Chris. (2000) "The rise and fall of the pyramid schemes in Albania." IMF Staff Papers. International Monetary Fund. Vol. 47, No. 1

International Crisis Group.(2003) "Albania: State of the Nation 2003." Tirana/Brussels. Balkans Report No 140.

Neza, Sami (2008) “Albania: Forecasts and Challenges.” Tirana: Southeast European Times. Feb.18, 2008 http://www.setimes.com/cocoon/setimes/xhtml/en GB /features/ setimes/articles/2008/02/18/reportage-01

Emily Pearce received her undergraduate degree from McGill University in Montreal. She recently completed her Masters degree in Political Science with a concentration on TransAtlantic Studies at the University of North Carolina at Chapel Hill. Through this program, she conducted studies on site at Charles University in Prague and the Institut d'Études Politiques in Paris. She has interned at several NGO's, including the Prague Security Studies Institute in Prague. After completing her dissertation on external governance and democracy promotion she did field work in Albania with the Centre for Economic and Social Studies. 